DOI https://doi.org/10.18551/rjoas.2018-09.20

\title{
EFFECTS OF INTENSIVE DISTRIBUTION AND SALES PROMOTION ON CORPORATE IMAGE AND CONSUMER-BASED BRAND EQUITY: A STUDY ON SUZUKI CAR CONSUMERS OF PT. SURYA BATARA MAHKOTA, EAST NUSA TENGGARA, INDONESIA
}

\author{
Langga Anderias Siwa Wunu \\ Department of Business Administration, Faculty of Social and Political Sciences, \\ University of Nusa Cendana, Indonesia
}

\author{
Alhabsji Taher, Notosubroto Suharyono, Kusumawati Andriani* \\ Department of Business Administration, Faculty of Administrative Science, \\ University of Brawijaya, Indonesia \\ *E-mail: andriani kusuma@ub.ac.id
}

\begin{abstract}
This research aimed to analyze the effect of Intensive Distribution and Sales Promotion on Corporate Image and Consumer-Based Brand Equity. The sampling was done using a multistage sampling technique, that was by selecting four regions (a city and three regencies) in East Nusa Tenggara, namely Kupang City, South Central Timor Regency, Belu Regency and Ende Regency with the total consumers of 1,402 people. The research results showed that intensive distribution had a significant effect on the corporate image and consumer-based brand equity; sales promotion had a significant effect onthe corporate image but had no significant effect on the consumer-based brand equity, and; the corporate image had significant effect onthe consumer-based brand equity. Future research is suggested to add other variables not included in this research model so as to create a more comprehensive model. Furthermore, we expect that future research can involve a larger size of samples, use other companies, and apply a comparative study model between several industrial companies.
\end{abstract}

\section{KEY WORDS}

Intensive distribution, sales promotion, corporate image, consumer-brand equity.

The phenomenon of competition in the current globalization era is increasingly directing the economic system of any country including Indonesia to the market mechanism which in turn positions marketers to always develop and capture market share. In this regard, product brands play a role as the biggest asset source for companies.Competitive market conditions, customer preferences and loyalty are the keys to the company's success (Durianto et al., 2014: 1). This marketing is a consumer perception, no longer a product battle. Consumer perception can be built by understanding the concepts of marketing, intensive distribution, sales promotion, corporate image, and consumer-based equity brand.

The problem examined in this research was related to the assumption that intensive distribution and sales promotion had not been effectively done, particularly in the marketing of four-wheeled motor vehicles, compared to the product and price elements. Therefore, intensive distribution and sales promotion became the variables studied in this research. Evans and Berman (1997: 422-423) stated that in intensive distribution, there is a large number of resellers from all types of companies (outlets). Intensive distribution objectives include broad markets, high channel revenues, sales volume and profits. This strategy is aimed at end consumers who are large in number and comfort-oriented, while organizational consumers focus on all types of service accounts expected from intermediaries. The marketing focus onend consumers can be in the form of mass advertising, nearest (strategic) locations, and items in inventory, while that on organizational consumer is related to product 
availability, usual communication, and superior services. The main weakness of intensive distribution is the limited control channel.

According to Angipora (2002), by using intensive distribution, companies expect to gain more sales and make consumers/ customers more familiar with their products. Manufacturers are constantly tempted to switch from exclusive or selective distribution to more intensive distribution with the aim to enlarge their market reach and sales. The intensive distribution strategy may help in the short term but often damage long-term performance. The distribution of products will be intensive if the products are placed in many stores and outlets to meet market needs. Differently, Yoo et al. (2000) suggested that to lift their product image and obtain assistance from retails, companies tend to distribute their products exclusively and selectively rather than intensively.

PT. SBM NTT is one of the holder agents of Suzuki brand (APM) in Nusa Tenggara area which has received a license from PT. Suzuki Indomobil Sales (PT. SIS) by establishing a Branch Office in Kupang in 2010 covering the area of NTT. NTT is a potential market for Suzuki cars because the archipelago territory covers the large islands of Flores, Sumba and western Timor; the small islands of Rote, Sabu, Alor, Solor, Adonara, Lembata and Komodo, and other smallest islands. NTT is one of the provinces in Eastern Indonesia directly adjacent to the Democratic Republic of Timor Leste, which can potentially market Suzuki cars to the country.

Suzuki cars are much in demand by the people of NTT with an increasing annual sales trend and the highest market share control compared to Toyota, Daihatsu, Honda, and Isuzu in which each automotive company as the sole brand holder agent (ATPM) is very competitive in capturing NTT market share. PT. SBM has expanded its marketing network in NTT by opening Suzuki car outlets spreading across 14 regencies/ cities with the aim to bring Suzuki closer in meeting consumer's vehicle needs.

This research aimed to test and explain: 1) the effect of intensive distribution on corporate image; 2 ) the effect of intensive distribution on consumer-based brand equity; 3 ) the effect of sales promotion on corporate image; 4) the effect of sales promotion on consumer-based brand equity; and 5) the effect of corporate image on consumer-based brand equity.

\section{REVIEW LITERATURE}

Every company is not separable from marketing activities to market its products. The essence of marketing activities relates to the identification and fulfilment of human and social needs so that the company's goal to meet human needs in a profitable way can be achieved well. According to American Marketing Association (AMA) in Kotler and Keller (2009), marketing is an organizational function and a series of processes to create, communicate, and deliver values to customers and to manage customer relationships in a way that benefits the organization and stakeholders. The marketing concept assumes that the key to achieving organizational goals more effectively than competitors is by creating, delivering, and communicating better customer values on the chosen target market.

The concept of holistic marketing is based onthe purpose of design development and the implementation of marketing programs, processes, and activities realizing the broad and interdependent marketing nature. Holistic marketing assumes that everything is meaningful, valuable, and important in marketing, and often needed in a broad perspective and integrated unity. The four broad components characterizing holistic marketing include relationship marketing, integrated marketing, internal marketing, and performance marketing or marketing with social responsibility (Kotler and Keller, 2009).

Here is the concept of four holistic marketing components: (1) Relationship marketing aims to build long-term relationships that are mutually satisfying with key people or organizations to obtain and retain business and customers. The key people or organizations for relationship marketing include: customers, employees, and marketing partners covering channels, suppliers, distributors, dealers, agents, and members of financial community such as shareholders, investors, and analysis; (2) Integrated marketing is to mix and adjust 
marketing activities to maximize individual and collective effects. The key theme of integrated marketing is a large number of different marketing activities that communicate or deliver values, and when coordinated, marketing activities can maximize the combined effect; and (3) Internal marketing aims to recruit, train, and motivate competent employees, so they are willing to serve customers well.

Based on the two opinions above, philosophically, marketing aims to create exchange relationships which are mutually beneficial for all parties involved in the exchange. Value exchange is not only madewith consumers but all parties involved in marketing activities. Thus, marketing activities are part of a growing society because value exchange between various members of society is very important for their survival.

Meanwhile, a marketing mix is part of integrated marketing, but the concept has inseparable relation to relationship marketing, internal marketing, and performance marketing. In integrated marketing, marketing activities emerge in all forms. McCarthy (1981) classified marketing activities as a means of the marketing mix of four broad types called "4P", covering product, price, place and promotion. According to Kotler and Keller (2009a), $4 \mathrm{P}$ symbolizes the view of manufacturers (producers) in which available marketing tools are to influence consumers, while in consumers' view, each marketing tool is designed to provide benefits to customers.

Kotler (2006) defined marketing mix as a set of marketing tools that companies use continuously to achieve marketing goals in the target markets. Moreover, according to Lamb et al. (2004), marketing mix is a unique combination of product, promotion, place and price strategies designed to produce mutually satisfying exchanges with the intended market. Differently, Lupiyoadi (2001) stated that marketing mix (4P) describes the meaning of tangible products. As for the marketing mix of intangible products (services), marketing experts add three elements (3P), namely people, process, and customer service. These three elements are related to the nature of services starting from production to consumption as an inseparable series and involving consumers by providing services directly. Booms and Bitmer in Kotler (2006) proposed additional 3P for service marketing, namely: people, physical evidence, and process because most of the provided services and employee selection, training, and motivation can make a huge difference in customer satisfaction.

The theoretical review related to the distribution channel, sales promotion, corporate image, and consumer-based brand equity variables is explained further below.

Intensive Distribution. A place is a combination of location and decision on distribution channels. The importance of location for services depends on the type and level of interaction that occurs. Interactions between service providers and customers have various types as follows: customers coming to service providers; service providers coming to customers; or distance business transaction between service providers and customers. Kotler and Armstrong (1998) explained that a place (distribution) includes company activities to make the products available to target consumers. The place used to supply services to target consumers is the key in the decision field. The consideration of decisions of places and channels is regarding how to deliver products/ services to customers, in which the products/ services must be placed.

Intensive distribution is when a company uses a large number of resellers. Intensive distribution is aimed to have a broad market coverage, high channel revenues, total sales, and profits, but the profit per unit is relatively low. This strategy is aimed at most consumers. The intensity of the distribution channel coverage has various attributes (Evan and Berman, 1997).

Similarly, Angipora (2002) argued that to determine the number of intermediaries used at each level of distribution channels including wholesalers and retailers, companies have three options of alternative strategies. The first strategy is intensive distribution, in which manufacturers place or distribute their products/ services in as many outlets as possible. This strategy is generally used for types of goods, such as tobacco products, soaps, snacks, and chewing gum because consumers need a lot of location convenience for these products. Thesecondstrategy is selective distribution, involvingthe use of more than a few intermediaries, but not all intermediaries are willing to sell certain products. The selective 
distribution strategy is commonly used by established companies and thosewhich are just looking for distributors. The third strategy is exclusive distribution, greatly limiting the number of intermediaries. This strategy can be used if the manufacturer wants to remain in control of the level and output of services offered by the intermediary. Moreover, this strategy involves an exclusive agreement plan.

Places or distributions include company activities to make products available for target consumers (Zeithaml and Bitner, 1996; and Payne, 2001). The selection of distribution location is influenced by cost, time speed, and the ease of the facilities needed (Zeithaml and Bitner, 1996). Differently, according to Payne (2001),the place of distribution in service marketing is influenced by the type of channels, intermediaries, outlet locations, transportations, storage, and channel management. Furthermore, Kotler (2006) stated that distribution or marketing channels are a set of institutions that perform all activities or functions used to distribute their products and ownership status from manufacturers (producers) to consumers.

Sales Promotion. According to Kotler (2006), promotion consists of four main tools or so-called a promotion mix, covering (1) advertising, referring to all forms of non-personal presentations and promotions of ideas, products or services through certain media paid by certain sponsors; (2) sales promotion, consisting of a set of different incentive tips, mostly short-term and designed to encourage customer or seller purchases faster and more largely than a certain product/ service; (3) public relations, requiring companies to not only have to deal constructively with customers, suppliers, and distributors but also a large group of public interests; and (4) personal selling, referring to the most effective tips for simplifying work operations, especially in shaping buyer preferences, beliefs, and actions.

Sales promotion is done by marketers by utilizing various ways to increase the attractiveness of the offered products and the product sales. Consumers who are uncertain about their choice of available alternatives tend to avoid products that offer invaluable perceived promotions (Simonson, et al., 1994). Lupioadi (2001) defined sales promotion as all activities intended to increase the flow of goods or services from manufacturers to final sales. Points of sales promotion consist of brochures, information sheets, and others. Sales promotion is addressed to 1) Customer, in the form of free offers, samples, demonstrations, coupons, cash refunds, prizes, contests, and warranties; 2) Intermediaries, in the form of free goods, discounts, advertising allowances, cooperative advertising, distribution contest, awards; 3) Salesforce, in the form of bonuses, awards, contests and prizes for the best sellers (best performers).

Corporate Image. In general, customers intend to buy products/ services from companies with a superior image to reduce risk.Mofokeng (2001) defined a corporate image as a valuable asset that must be managed well by the company. A good corporate image can help develop product/ service sales through increased customer satisfaction and loyalty and attract both investors and employees in the future. However, a good corporate image can also weaken the negative effect of competitors and allow the company to achieve a higher level of profit (Kim et al., 2011 and Amini et al., 2012).

According to Keller (1993), the term 'corporate image' refers to a specific association stored in customer memories of a certain company. The corporate image in customer memories covers institutional image, functional image, and commodity image (Lin and Lu, 2010). Corporate image is considered as one of the most important strategy providing a basis for companies to build a strong and long-term competitive advantage compared to competitors in a market (Boyd et al., 2010). Corporate image is a valuable asset that must be managed well by companies with certain types/ identities to get feedback from all parties in the certain market regarding the corporate identity credibility created by the organization (Abratt and Mofokeng, 2001; Cretu and Brodie, 2007).

Customer-Based Brand Equity. Corporate brands act as the strongest navigation tool for stakeholders including investors, employees, and consumers (Bridson and Mavondo, 2011). In the condition of intense competition, many companies project strong and positive reputations to stakeholders, covering employees, consumers, investors, and the society. Companies must strive to project images that are stable, attractive, aggressive, and variously 
public-oriented yet focused on a number of specific areas, and smart employees in investing. The ability to meet various needs of stakeholders can help gain positive feelings for companies.

American Marketing Associations (AMA) defined a brand as a name, term, sign, symbol, design, or combination thereof, which is intended to identify goods/ services from a seller or group of sellers and differentiate them from competitors (Kotler and Keller, 2006, 2009). Furthermore, Kotler and Keller identified brand as a product/ service that adds dimensions that can differentiate it in several ways from other products/ services designed to meet the same needs.

Customer-based brand equity is a study of brand equity measurement in customer/ consumer-based contexts, where consumer responses on a brand name are evaluated (Keller, 1993, Shocker et al., 1994) and the effect on brand options and purchase interests are expanded (Cobb-Walgren et al., 1995), so are the intention of repeat purchase (Huang et al., 2014, Kazemi et al., 2013, Bojei and Hoo, 2012), and brand alliances (Rao and Manroe, 1989).

Kotler and Keller (2009) stated that to create strong brand equity, a certain product often makes the brand itself have a successful market share. Strong brand equity will have an impact on other brands of similar products. Therefore, the highly competitive automotive industries and retailers in which many businesses are trying to acquire customers must be accompanied by a marketing strategy that creates their equity. Senthilnathan and Tharmi (2012) suggested that a positive and memorable corporate brand image will provide competitive business capabilities. Thus, customer-based brand equity is an asset of brand dimensions.

Aaker (1991, 1996a, 1996b) divided brand equity into four main dimensions, namely brand awareness, brand associations, perceived quality, and brand loyalty. Furthermore, Keller (2003) classified brand awareness and brand image into brand knowledge. Yoo et al.'s (2000) study adopted the model of brand equity from Aaker (1991). Brand equity is a value where if consumers associate with a brand, their perceptions will be directed to all the product advantages of the name, which ishigher than other brands (Aaker, 1991).

\section{METHODS OF RESEARCH}

This research is an exploratory research, which explains the effect of one or several variables on another or several other variables using primary data. The research model developed is expected to describe more clearly the relationship between variables being analyzed, give research implications that are useful for the development of science, and serve as a method to solve problems in the field. This research was conducted in East Nusa Tenggara (NTT), in which the object used as the unit of analysis was the consumers of Suzuki cars sold by PT. Surya Batara Mahkota (PT. SBM), NTT.

The population of this research was all Suzuki car consumers of PT. SBM NTT in 15 regencies/ cities of NTT Province in 2015, amounted to 1,782 people. The sampling was done using a multi-stage sampling technique, that was by selecting four regions in East Nusa Tenggara, namely Kupang City, South Timor Tengah Regency, Belu Regency and Ende Regency with the total population of 1,402 people.Of the population, 144 consumers were taken as the research sample by using Slovin formula with a $9 \%$ precision level. In each region, the sampleswere taken proportionally while the respondents were taken accidentally.

The primary data collection in this research was done using questionnaires and interviews while the secondary data were obtained from the company through a document study. The instruments used to collect primary data directly from consumers (respondents) were questionnaires. Since the sampling was done accidentally, the researchers assisted by enumerators and students regularly visiting each of the main Suzuki car dealers of PT. SBM NTT in the four sample regions. The prospective respondents who were in accordance with the target population criteria were given questionnaires to be filled out.

Data that had been collected were then examined, tabulated and analyzed. The data analysis was conducted using descriptive statistical analysis and Generalized Structure 
Component Analysis (GSCA) techniques. A descriptive statistical analysis is to describe or interpret tabulated data as they are without intending to draw general conclusions or generalizations. Meanwhile, descriptive analysis is the transformation of raw data into a form that is easily understood or interpreted. Furthermore, Simamora (2004: 231) stated that descriptive analysis aims to describe the characteristics of each variable in samples.

Hypothesis:

Based on the objectives, review literature and empirical studies, the variables of this research (intensive distribution, sales promotion, corporate image, and consumer-based brand equity) served as temporary answers in testing and analyzing the effect of exogenous variables on endogenous variables. Furthermore, to achieve the research objectives, the researchers proposed the following five hypotheses according to the theoretical reviews and the results of previous research:

- $\mathrm{H} 1$ : Intensive distribution has a significant effect on corporate image;

- H2: Intensive distribution has a significant effect on consumer-based brand equity;

- H3: Sales promotion has a significant effect on corporate image;

- H4: Sales promotion has a significant effect on consumer-based brand equity;

- H5: Corporate image has a significant effect on consumer-based brand equity. The model of the research hypotheses is visualized in Figure 1.

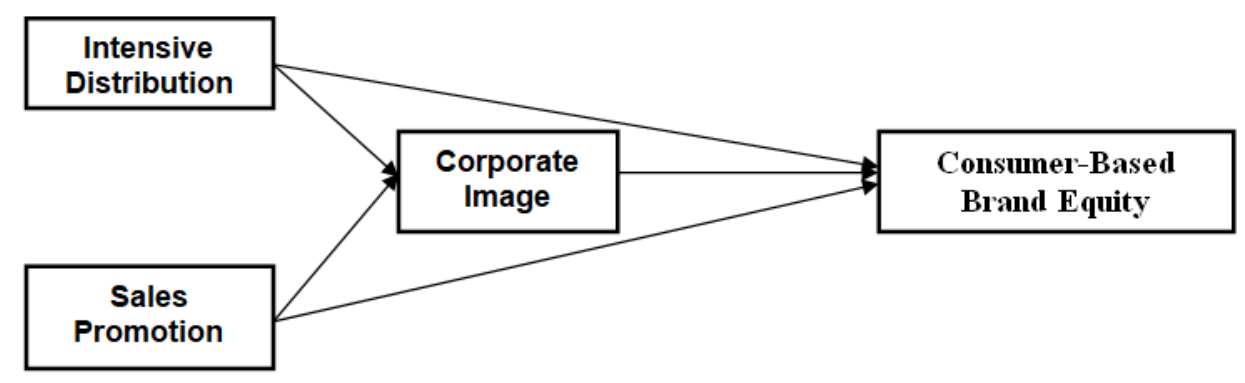

Figure 1 - Research Hypothesis Model

\section{RESULTS AND DISCUSSION}

Convergent Validity Test. The outer loading results of 30 items and 15 indicators of the 4 latent variables measured were obtained through GSCA Bootstrap calculation, generatinga factor loading or critical ratio (CR) value equal to the $T$ statistical value. If the factor loading value was positive and greater than 0.6 , the weight value was above 0.4 , and the CR value was greater than the $T_{\text {table }}(1.96)$, the effect was said to be significant.

The convergent validity test results of the research variables (Intensive Distribution, Corporate Image, and Consumer-Based Brand Equity) showed that all the items forming the indicators of the four variables had a factor loading value greater than 0.5 .

The Intensive Distribution (ID) variable was measured using four indicators and eight statement items as the parameters. The indicators were: Product Availability (ID2), Product Variety (ID2), Delivery Period (ID3), and Distribution Channel Effectiveness (ID4). The loading factor values of the 8 statement items ranged from the lowest of 0.867 (ID2.1) to the highest of 0.957 (ID1.2). That is, that all the items of the Intensive Distribution variable used in this research met the requirement of convergent validity.

The Sales Promotion (SP) variable was measured using four indicators and eight statement items as the parameters. The indicators were: Lottery (SP1), Contest (SP2), Price Promotion (SP3), and Bonus (SP4). The factor loading values of the 8 statement items ranged from the lowest of 0.864 (SP4.2) to the highest of 0.904 (SP1.1). That is, all the items of the Sales Promotion variable used in this research met the requirement of convergent validity.

The Corporate Image $(\mathrm{Cl})$ variable was measured using three indicators and six statement items as the parameters. The indicators were: Institutional Image (Cl1), Functional Image $(\mathrm{Cl} 2)$, and Commodity Image $(\mathrm{Cl} 3)$. The factor loading values of the six statement 
items ranged from the lowest of 0.876 (Cl3.2) to the highest of 0.893 (CPI.1). In other words, all the items of the Corporate Image variable used in this research met the requirement of convergent validity.

The Consumer-Based Brand Equity (CBE) variable was measured using four indicators and eight statement items as the parameters. The indicators included: Brand Awareness(CBE1), Brand Association (CBE2), Perceived Quality (CBE3), and Brand Loyalty (CBE4). The factor loading values of the eight statement items ranged from the lowest of 0.874 (CBE4.1) to the highest of 0.893 (CBE1.2). That is, all the items of the ConsumerBased Brand Equity variable used in this research met the requirement of convergent validity.

Overall, the convergent analysis results of the 15 indicators showed that all the items measuring the indicators, covering: (a) product availability, product variety, delivery period, and distribution channel effectiveness; (b) lottery, exhibition contest, price promotion and bonus; (c) institutional image, functional image, and commodity image; (d) brand awareness, brand association, perceived quality, and brand loyalty, resulted in a factor loading value> 0.5 with a CR value $>1.96$. Thus, all the items were declared valid or able to measure the variables.

Discriminant Validity Test. Discriminant validity test, which is used to determine the discriminant validity of each indicator in measuring latent variables, can be done by comparing the value of Average Variance Extracted (AVE) with the correlation between indicators. An indicator is said to have a good discriminant validity if the AVE value is $>0.50$ (Ghozali, 2008).

The results of discriminant validity analysis showed that the lowest AVE value of the 15 indicators was 0.739 on the indicators of exhibition contest (SP2) and price promotion (SP3), while the highest AVE value was 0.877 on the product availability indicator (ID1). That is, the AVE values of all the indicators were greater than the standard 0.50 . Thus, all the indicators measuring the latent variables (intensive distribution, sales promotion, corporate image, and consumer-based brand equity) had good discriminant validity. Since the results of discriminant validity test showed that all the indicators were good, it wasconcluded that all the indicators measuring each latent variable were fulfilled.

Consistency Reliability Test. Consistency reliability is the extent to which an instrument is able to consistently measure phenomena that have been designed to be studied. The reliability test of latent variables in GSCA is through internal consistency reliability, which is to measure the reliability of indicator groups on latent variables formed using Cronbach's alpha values. If the Cronbach's alpha value $\geq 0.6$, the variable can be declared reliable (Ghozali, 2008).

The consistency reliability analysis results showed that the lowest Cronbach's Alpha value of the 15 indicators was 0.662 on the Bonus indicator (SP4) and the highest Cronbach's Alpha value was 0.858 on the Product Availability indicator (ID1). That is, the Cronbach's Alpha values of all indicators were greater than the standard (>0.60). Thus, all the indicators measuring the latent variables (intensive distribution, sales promotion, corporate image, and consumer-based brand equity) were declared reliable or met the requirement of consistency reliability, so that the indicators could be used to measure or explain the latent variables.

Inner Model Test Results (Research Hypothesis). Based on the theories, empirical studies, and the research hypothesis model, the researchers developed an inner model explaining the correlation between exogenous latent variables and endogenous latent variables based on the substantive theory. The path coefficient value of the effects of exogenous latent variables on endogenous latent variables was obtained through GSCA calculation and significance test with bootstrapping, generating a critical ratio (CR) equal to the T-value.

In the hypothesis testing, the direct effect of exogenous variables on endogenous variables can be seen from the critical ratio (CR) values. As seen in Table 1 below,the significant effects of exogenous variables on endogenous variablesare characterized by a starred critical ratio $(C R)$ value of $\geq t$-table $(t=1.96$, alpha $=5 \%)$, 
Table 1 - Structural Model Test Results (Inner Model)

\begin{tabular}{|c|c|c|c|c|c|c|}
\hline \multirow{2}{*}{ Hypothesis } & \multirow{2}{*}{ Path } & \multicolumn{3}{|c|}{ Path Coefficients } & \multicolumn{2}{c|}{ Description } \\
\cline { 3 - 6 } & & Estimate & SE & CR & Significant & Accepted \\
\hline $\mathrm{H} 1$ & $\mathrm{ID} \rightarrow \mathrm{Cl}$ & 0,208 & 0,033 & 6,30 & Significant & Accepted \\
\hline $\mathrm{H} 2$ & $\mathrm{ID} \rightarrow \mathrm{CBE}$ & 0,110 & 0,039 & 2,82 & Significant & Accepted \\
\hline $\mathrm{H} 3$ & $\mathrm{SP} \rightarrow \mathrm{Cl}$ & 0,117 & 0,032 & 3,66 & Not significant & Rejected \\
\hline $\mathrm{H} 4$ & $\mathrm{SP} \rightarrow \mathrm{CBE}$ & 0,049 & 0,029 & 1,69 & Significant & Accepted \\
\hline $\mathrm{H} 5$ & $\mathrm{Cl} \rightarrow \mathrm{CBE}$ & 0,410 & 0,032 & 12,81 & $\mathrm{CR}^{*}=$ \\
\hline
\end{tabular}

Source: Processed GSCA Analysis Results, 2017. Notes: ID = Intensive Distribution; SP = Sales Promotion; $\mathrm{Cl}=$ Corporate Image; $\mathrm{CBE}=$ Consumer-Based Brand Equity.

The hypotheses with a starred CR value of >the t-table (1.96) were accepted, indicating that there was a significant effect of exogenous variables on endogenous variables. The accepted hypotheses were $\mathrm{H}_{1}, \mathrm{H}_{2}, \mathrm{H}_{3}$, and $\mathrm{H}_{5}$. In contrast, the fourth hypothesis $(\mathrm{H} 4)$ was rejected because the effect of the exogenous variable on the endogenous variable was not significant, indicated by a $C R$ value not starred and less than the t-table $(<1.96)$.

The Effect of Intensive Distribution on Corporate Image. Based on the research results, Intensive Distribution had a positive and significant effect on the Corporate Image with a path coefficient value of 0.208 , CR value of $6.30^{*}(>1.96)$ at the $P$ level of 0.05 . The test results supported Hypothesis 1 , so $\mathrm{H}_{1}$ was accepted. The statistical evidence indicates that the path coefficient was positive and significant. The positive path coefficient means that if the intensive distribution increased, the corporate image would get improved. The theoretical implication of this empirical researchstates that any increase or improvement in intensive distribution will lead to a better corporate image.

This research provides empirical evidence or support the theory of intensive distribution (Evan and Berman, 1997) suggesting that resellers are large in quantity, used by all types of companies (outlets), have broad markets, high channel revenues, sales volume and profits, great number of end consumers, nearest (strategic) location, product availability, and comfort-oriented (Angipora, 2002).

Companies can choose alternative distribution channels to be used, covering intermediaries, exclusive distribution, selective distribution and intensive distribution (Evans and Berman, 1997; Kotler, 2006). Places or distributions include company activities to make products available for target consumers (Zeithaml and Bitner, 1996; and Payne, 2001). The selection of distribution location is influenced by cost, time speed, and the ease of the facilities needed (Zeithaml and Bitner, 1996). Differently, according to Payne (2001), the place of distribution in service marketing is influenced by the type of channel, intermediary, outlet location, transportation, storage, and channel management. Furthermore, Kotler (2006) stated that distribution or marketing channels are a set of institutions that perform all activities or functions used to distribute their products and ownership status from manufacturers (producers) to consumers.

This research supports the theory of corporate image by Lin and Lu (2010) stating that corporate image in consumer or customer memories covers institutional image, functional image, and commodity image. Boyd et al. (2010) asserted that corporate image is one of the most important strategies that provide a basis for companies to build a strong and long-term competitive advantage compared to competitors in a market. Corporate image is a valuable asset that must be managed well by companies with certain types/ identities to get feedback from all parties in certain markets regarding the corporate identity credibility created by the organization (Abratt and Mofokeng, 2001; Cretu and Brodie, 2007). The term 'corporate image' refers to special associations stored in the memories of certain companies' customers (Keller, 1993).

This research supports Kim and Hyun (2011) and Amini et al. (2012) finding that performance of distribution channels as an attempt of marketing mix has a positive and significant effect on the corporate image. Based on the concept of corporate image (Lin and 
Lu, 2010), the Corporate Image variable measured using three indicators (institutional image, functional image, and commodity image) has various levels influenced by intensive distribution. Linear with this, the good corporate image of Suzuki is caused by the increased intensive distribution of Suzuki cars. On another side, Yoo et al. (2000) revealed that to lift their product image and obtain assistance from retails, companies tend to distribute their products exclusively and selectively rather than intensively.

The Effect of Intensive Distribution on Consumer-Based Brand Equity. The results of this research showed that Intensive Distribution had a positive and significant effect on the Consumer-Based Brand Equity with a path coefficient value of 0.110 , CR value of 2.82* $(>1.96)$ at the $P$ level of 0.05 . The test results supported Hypothesis 2, meaning that $\mathrm{H}_{2}$ was accepted. The statistical evidence indicates a positive and significant path coefficient value. That is, if the intensive distribution increased, the consumer-based brand equity would also get higher. This empirical research theoretically implies that any increased intensive distribution will lead to increased consumer-based brand equity.

This research is consistent with Aaker's theory (1991) stating that brand equity is a set of assets and liabilities associated with a brand, name and symbol that can increase or decrease the value of a product or service, both for the company and consumer (Aaker, 1996a; Durianto et al., 2001; Keller et al., 2012). Brand equity is the added value given to products and services, which can be reflected in the way consumers think, feel, and act in relation to the brand, price, market share, and the profitability resulted from the brand (Kotler and Keller, 2009; Durianto et al.,2001).

This research strengthens previous studies of Amini et al. (2012) and Al-Dmour et al. (2013) finding that a distribution channel is a marketing mix element that positively and significantly influences consumer-based brand equity consisting of brand awareness, brand association, brand image, perceived quality and consumer-brand loyalty. Meanwhile, Kim and Hyun (2011) found that the performance of distribution channels had a positive and significant effect on brand awareness, brand association, and brand loyalty, excluding perceived quality. Differently, Kazemi et al. (2013a) found that the element of distribution arrangement had a significant effect on brand loyalty, but did not have a significant effect on brand awareness and perceived quality.

The Effect of Sales Promotion on Corporate Image. In this research, Sales Promotion had a significant effect on the corporate image, indicated by the path coefficient value of $0.161, \mathrm{CR}$ value of $4.60^{*}(>1.96)$ at the $\mathrm{P}$ level of 0.05 . These results highly supported Hypothesis 3 , so $\mathrm{H}_{3}$ was accepted.The statistical evidence shows a positive and significant path coefficient value. The positive path coefficient indicates that if the sales promotion increased, the corporate image would also be better. The theoretical implication of this empirical research is that any increase or improvement in sales promotion will generate an increase in corporate image.

This research supports the theory of sales promotion (Lupioadi, 2001: 109) stating that sales promotion includes all activities intended to increase the flow of goods or services from manufacturers (producers) to final sales. Points of sales promotion consist of brochures, information sheets, price promotion, price lists, and others. Sales promotion can be given to Customer, in the form of free offers, samples, demonstrations, coupons, cash refunds, prizes, contests, and warranties.

Based on the opinion of Lupioadi (2001) regarding various sales promotion activities, the effect of the Sales Promotion variable on the corporate image in this research was measured using four indicators (lottery, exhibition contest, price promotion, and bonus). This research supports the finding of Kim and Hyun (2011) and Amini et al. (2012) that promotional performance has a positive and significant effect on the corporate image.

The Effect of Sales Promotion on Consumer-Based Brand Equity. The results of this research suggested that there was no significant effect of Sales Promotion on the ConsumerBased Brand Equity. It was shown by the path coefficient value of 0.049 and $C R$ value of 1.69 (less than 1.96) at the $P$ level of 0.05 . The test results did not support Hypothesis 4, so $\mathrm{H}_{4}$ was not accepted. The statistical evidence suggests that the path coefficient was positive yet insignificant. It may happen to brands that have been well-known, accepted, trusted and 
liked by people because these brands no longer need high sales promotion. That is, the companies with well-known branded products can reduce sales promotions, automatically lowering sales promotion costs.

This research supports Kim and Hyun (2011) finding that promotional efforts do not significantly affect the three dimensions of brand equity, covering brand loyalty, brand awareness, and brand association. Meanwhile, Hajipour et al. (2013) found that the promotion factor had no significant effect on perceived quality.

The Effect of Corporate Image on Consumer-Based Brand Equity. Based on the results of this research, the Corporate Image of Suzuki had a positive and significant effect on the Consumer-Based Brand Equity with a path coefficient value of 0.410 , CR value of $12.81^{*}$ (> 1.96) at the $P$ level of 0.05 . The test results supported Hypothesis 5, meaning that $\mathrm{H}_{5}$ was accepted. The statistical evidence shows a positive and significant path coefficient value, meaning that an increase in the corporate image would lead to an increase in the consumerbased brand equity as well. This empirical research theoretically implies that any increase or improvement in a corporate image will generate an increase in the consumer-based brand equity.

This research supports the theory of Lin and Lu (2010) stating that a company's image consists of three indicators, namely institutional image, functional image, and commodity image. Furthermore, the corporate image variable measured using the three indicators has various levels of influence on consumer-based brand equity so as to improve the corporate image continuously in the long run.

\section{CONCLUSION}

Intensive distribution has a significant effect on corporate image. The positive path coefficient of the effect indicates that an increased intensive distribution of PT. SBM will improve the corporate image. This empirical research theoretically implies that if intensive distributionincreases, the corporate image will also be better $\left(\mathrm{H}_{1}\right.$ is accepted).

Intensive distribution has a significant effect on consumer-based brand equity. The positive path coefficient of the effect means that an increased intensive distribution of PT. SBM will improve the consumer-based brand equity. This empirical research theoretically implies that if intensive distribution increases, the consumer-based brand equity will also get strengthened $\left(\mathrm{H}_{2}\right.$ is accepted).

Sales promotion has a significant effect on corporate image. The positive path coefficient of the effect signifies that an increase in PT. SBM's sales promotion will improve the corporate image. This empirical research theoretically implies thatif sales promotion increases, the corporate image will also be better $\left(\mathrm{H}_{3}\right.$ is accepted).

Sales promotion has no significant effect on consumer-based brand equity. The statistical evidence shows a positive yet insignificant path coefficient value, meaning that the increase in PT. SBM's sales promotion does not significantly increase the consumer-based brand equity. The theoretical implication of this empirical research is that an increase in sales promotion does not always improve the consumer-based brand equity. It does not support $\mathrm{H} 4\left(\left(\mathrm{H}_{4}\right.\right.$ is rejected $)$.

Corporate image has a significant effect on consumer-based brand equity. The positive path coefficient of the effect indicates that any increase in the corporate image of PT. SBM will improve the consumer-based brand equity. This empirical research theoretically implies thatif corporate image increases, the consumer-based brand equity will also get improved $\left(\mathrm{H}_{5}\right.$ is accepted).

\section{SUGGESTIONS}

We propose that further research should be undertaken by considering as follows:

- Adding variables that have not been included in this research model to obtain a more comprehensive research model; 
- Using a larger size of samples, focusing onother companies than automotive companies and taking other places for a longer period of time;

- Making a comparative study between industrial companies;

- Examining consumer attitudes towards the marketing strategy of WOM (Word of Mouth) through social network sites (Facebook, WhatsApp, Twitter, Youtube, and Instagram).

We believe that the strong points of this research can give the following contributions:

- As information materials for the company of Suzuki Indonesia, especially the Suzuki car dealers of PT. SBM NTT as the brand holder agent in increasing the effectiveness of intensive distribution, sales promotion, corporate image, and consumer-based brand equity;

- As a reference for the Regional Government in making government policies in the form of regulations, permits, guidance and socialization so that the Suzuki company of PT. SBM NTT can extend the marketing network of Suzuki cars in all regencies/ cities;

- As a consideration for investors in supporting the government policy regarding the conversion of oil fuel $(B B M)$ to gas fuel $(B B G)$ forsome vehicles with the condition that gas refuelling stations ( $S P B G)$ are provided or available.

\section{LIMITATION OF THE STUDY}

Inevitably, a number of limitations could have influenced the results obtained in this research. As this research was conducted in East Nusa Tenggara Province which is geographically an archipelago, the sample of areas was limited to two islands and four regions (a city and three regencies). Furthermore, this research only involved Suzuki car consumers of PT. SBM NTT with a self-owned status and the use only for household purposes, so the generalization of this research was also limited. Besides, the marketing strategy of WOM from the consumers to others was still conventional and ineffective. The last, there are still other exogenous variables that actually can explain the endogenous variables but were not included in this research model.

\section{REFERENCES}

1. Aaker, D.A. (1991). Managing Brand Equity: Capitalizing on the Value of a Brand Name, the Free Press. New York.

2. Aaker, D.A. (1996a). Building Strong Brands. The Free Press. New York.

3. Aaker, D.A. (1996b). "Measuring Brand Equity across Product and Markets", California Management Review, 38 (3): 102-120.

4. Abratt, R. and Mofokeng, T.N. (2001). "Development and Management of corporate image in South Africa", Eur J Mark 35 (3/4): 368-386.

5. Al-Dmour, H., Al-Zu'bi, Z.M.F. and Kakeesh, D. (2013). "The Effect of Services Marketing Mix Elements on Customer-Based Brand Equity: An Empirical Study on MobileTelecom Service Recipients in Jordan". International Journal of Business \& Management 8 (11): $13-26$.

6. Amini, A. (2010). "A Survey and Comparison of the Brand Equity of Iran and South Korea Home Appliance According to the Viewpoints of Tehran City Retailers", Thesis for SeniorGraduate, by Directed Hamidreza Hasanzadeh, Qom, Management College. Tehran University.

7. Amini, A., Mahdi, D., Minoo, A.andZahra, A. (2012). "Effectiveness of Marketing Strategies and Corporate Image on Brand Equity as a Sustainable Competitive Advantage", Interdisciplinary Journal of Contemporary Research in Business (IJCRB) June 4 (2): $192-205$.

8. Angipora, M.P. (2002). Dasar-Dasar Pemasaran, Edisi 2, PT. Raja Grafindo Persada. Jakarta. 
9. Bataineh, A.Q. (2015). "The Impact of Perceived e-WOM on Purchase Intention: TheMediating Role of Corporate Image".International Journal ofMarketing Studies 7 (1): $126-137$.

10. Bojei, J. and Hou, Ch.W. (2012). "Brand Equity and Current Use as The New Horizon for Repurchase Intention of Smartphone", International Journal of Business and Society, 13 (1): $33-48$.

11. Boyd, B.K., Bergh, D.D. and Ketchen, Jr.D.J. (2010). "Reconsidering the reputationperformance relationship: A resource-based view". Journal of Management, 36 (3): 588 609.

12. Bridson, K. and Macondo, F. (2011). "Corporate Image in The Leisure services sector", Journal of Services Marketing, 25 (3): $190-201$.

13. Brown, T.J., Barry, T.E., Dacin, P.A. and Gunst, R.F. (2005). "Spreading the word Investigating antecedents of consumers' positive word-of-mouth intentions and behaviours in retailing contexts". Journal of the Academy of Marketing Science, 33:

14. Cretu, A.E.and Brodie, R.J.(2007)."The Influence of Brand Image and Company Reputation Where Manufacturers Market to Small Firms: A Customer Value Perspective", industrial marketing Management 36 (2): 230-240.

15. Cobb-Walgren, C.J., Ruble, C.A. and Donthu, N. (1995). "Brand Equity, Brand Preference, and purchase intent", Journal of Advertising 24: 25-40.

16. Durianto, D., Sugiarto. dan Sitinjak,T. (2004). Strategi Menaklukkan PasarMelalui Riset Ekuitas dan Perilaku Merek, Cetakan Kedua.Gramedia Pustaka Utama. Jakarta.

17. Evans, J.R.andBerman, B. (1997). Marketing, Seventh Edition, Prentice-Hall, Inc.

18. Ghozali,I. (2008). Generalized Structured Component Analysis (GSCA).Badan Penerbit Universitas Diponegoro. Semarang.

19. Ghozali,I. (2011). Model Persamaan Struktural Konsep dan Aplikasi Dengan ProgramAMOS 19.0. Badan Penerbit Universitas Diponegoro. Semarang.

20. Hajipour, B., Bavarsad, B. andZarei, E.S. (2013). "Effect of Marketing Factors on Brand Relationship Equity and Affects the Customers' Purchase Intention", Journal of Management ResearchISSN 1941-899X, 5 (1): 317 - 332.

21. Haryono, S., Suharyono., Achmad, F.D.H.and Imam, S. (2015). "The Effects of ServiceQuality on Customer Satisfaction, Customer Delight, Trust, Repurchase Intention, and Word of Mouth". European Journal of Business and Management 7 (12): 36 - 48.

22. Huang, Chun-Chen., Szu-Wei, Y., Cheng-Yi, L. and Te-Pei, Ch. (2014)."The Relationship Among Brand Equity, Customer Satisfaction, and Brand Resonance to Repurchase Intention of Cultural and Creative Industries in Taiwan". The International Journal of Organizational Innovation, January 6 (3): 106-120.

23. Kazemi, A., Hossein, R.D.A. and Nastaran, K. (2013a). "Analyzing the Effect of Customer Equity on Repurchase Intentions", International Journal of Academic Research in Business and SocialSciences June 3 (6): 78-92.

24. Kazemi, A., Seyed, Y.H. and Mahboubeh, M. (2013b). "An Analysis of Influential Factors of Brand Equity and Its Impact on Consumer Buying Decision-The Selected Branches of Mellat Bank in Bushehr City as Case Study", International Journal of AcademicResearch in Business and Social SciencesNovember 3 (11): 422-432

25. Kim, Ji-Hern. and Hyun, Y.J.(2011). "A Model to Investigate The Influence of MarketingMix Efforts and Corporate Image on Brand Equity in The it Software Sector", Industrial MarketingManagement 40: 424-438

26. Kim, K.H., Jeon, B.J., Jung, H.S., Lu, W. and Jones, J. (2011). "Effective Employment Brand Equity Through Sustainable Competitive Advantage, Marketing Strategy, and Corporate Image", Journal of Business Research, 64: 1207-1211

27. Keller, K.L. (1993). "Conceptualizing, Measuring, and Managing Customer-Based Brand Equity", Journal of Marketing 57(1): 1-22.

28. Keller, K.L. (2003). Strategic Brand Management: Building, Measuring, andManaging Brand Equity, (2nd ed.), Englewood Cliffs, NJ: Prentice-Hall.

29. Kotler, P. (2006). Manajemen Pemasaran, Terjemahan Edisi Keenam. Jilid 1, Erlangga. Jakarta. 
30. Kotler, P. andKeller, K.L.(2006). Marketing Management, $12^{\text {Th }}$ International Edition, Pearson, Prentice Hall, New Jersey.

31. Kotler, P. and Keller, K.L. (2009). Manajemen Pemasaran. Translated by B. Sabran Jakarta: Erlangga.

32. Kotler, P. and Gary, A. (2006). Dasar-dasar Pemasaran, Translated by A. Sindoro. Kelompok Gramedia. Jakarta.

33. Lamb, Ch.W., Josep, F., HairJr. and Carl, McDaniel. (2004). Pemasaran. Salemba Empat. Jakarta.

34. Lin, Long-Yi. and Ching-Yuh, Lu. (2010). "The Influence Of Corporate Image, Relationship Marketing, And Trust On Purchase Intention: The Moderating Effects Of Word-Of-Mouth". Tourism Review 65 (3): 16-34. @ Emerald Group Publishing Limeted, ISSN 1660-5373.

35. Lupiyoadi, R. (2001). Manajemen Pemasaran Jasa: Teori dan Praktik. Salemba Empat. Jakarta.

36. McCarthy, J. (1981). Basic Marketing: A Managerial Approach.Homewood, II.; Richard D. Irwin.

37. Payne, A. (1993). The Essence of Services Marketing, Prentice Hall International (UK).

38. Payne, A. (2001). The Essence of Services Marketing(PemasaranJasa),Translated byF. Tjiptono. Andi. Yogyakarta.

39. Senthilnathan, S. andTharmi, U.(2012). "The Relationship of Brand Equity to Purchase Intention", The IUP Journal of MarketingManagement XI (2): 7 - 26

40. Shirsavar, H.A., Shahram, G. and Amin, M.A. (2012). "A Study of Factors influencing Positive Word of Mouth in the Iranian banking Industry, Middle-East". Journal of scientific research, 11(4): 454-460.

41. Simamora,(2004). Analisis Multivariat Pemasaran. PT, GramediaPustakaUmum. Jakarta.

42. Sedaghat, N., Sedaghat, M.andMoakher, A.K.(2012). "The Impact of Promotional Mix Elements on Brand Equity", American Journal of Scientific Research, Issue 43: 5 -15.

43. Shocker, A. D., Srivastave, R.K. and Reukert, R.W. (1994). "Challenges and Opportunities Facing Brand Management: An Introduction to Special Issue", Journal of Marketing Research 31: 149 -158.

44. Simonson, I., Zic, C.andO'curry, S. (1994). "Experimental Evidence on the Negative Effect of Product Features and Sales Promotions on Brand Choice", Marketing Science 13: $23-40$.

45. Rao, A.R. and Monroe, K.B. (1989). "The Effect of Price, Brand Name, and Store Name on Buyers' Perceptions of Product Quality: An Integrated Review", Journal of Marketing Research 26 (3): 351-357.

46. Yoo, B. (2000). "An Examination of Selected Marketing Mix Elements and Brand Equity", Journal of the Academy of Marketing Science 28 (2): 195-212.

47. Zeithaml, A.V.and Bitner, M.J.(1996).Services Marketing, The McGraw Hill Companies. New York.

48. Zeithaml, A.V., Bitner, M.J.and Gremier, D.D. (2006). Services Marketing: Integrating Customer Focus across the Firm, 4th ed., The McGraw-Hill. New York, NY. 